\title{
The effectiveness of local wisdom-based static fluid modules in the wetlands environment
}

\author{
Mustika Wati $^{\text {a }}$, Misbah Misbah ${ }^{\text {b }}$, Surya Haryandi ${ }^{c}$, Dewi Dewantara ${ }^{\text {d }}$ \\ Universitas Lambung Mangkurat. Jalan Brigjen H. Hasan Basry, Banjarmasin 70123, Indonesia \\ a mustika_pfis@ulm.ac.id, b misbah_pfis@ulm.ac.id, c surya.haryandi@gmail.com, d dewantarafisika@gmail.com \\ * Corresponding Author.
}

Received: 14 August 2020; Revised: 28 August 2020; Accepted: 3 September 2020

\begin{abstract}
This study aims to describe the effectiveness of static fluid module based on local wisdom in the wetlands environment. This study is a research and development study and uses the 4D model modified. The effectiveness of the module is measured using a learning outcome test. The subjects of this study were sixty grade XI students from two public high schools in Banjarmasin city. The result of the analysis showed that the effectiveness of teaching materials have a medium category. The result indicates that the static fluid module based on local wisdom in the wetland environment is effective so that they can be used in the learning process in the classroom, at the high school level.

Keywords: local wisdom; static fluid module; wetland environment
\end{abstract}

How to Cite: Wati, M., Misbah, M., Haryandi, S., \& Dewantara, D. (2020). The effectiveness of local wisdom-based static fluid modules in the wetlands environment. Momentum: Physics Education Journal, 4(2), 102-108. https://doi.org/10.21067/mpej.v4i2.4769

\section{Introduction}

Physics is one of the branch of science that explain a natural phenomenon and daily events using existing concepts and laws. Physics in high school aimed to implement the basic knowledge of physics and scientific method through experiment as a foundation in developing students' potential. This shows that the main focus in studying physics is to use facts, laws, principles and theories in everyday life and surrounding phenomena (Zahro et al., 2017). Therefore, physics cannot be separated from the environment around where the students learn so that learning is more meaningful (Anissa et al., 2020; Hasani et al., 2019).

One way that can make learning more meaningful is the integration of learning with local wisdom in student environments (Oktaviana et al., 2017; Wati et al., 2017). Local wisdom is custom or characteristic found in an area (Utari et al., 2016). Learning based on local knowledge will help students meet their goals in learning physics. Also, students will be more comfortable to visualize the application of the material in everyday life. Local wisdom can be contained in teaching materials. This learning approach using local wisdom can motivate students to relate the knowledge and apply every context found in their lives (I. Ihsan et al., 2019; Misbah \& Wati, 2020).

The location of South Kalimantan on wetlands can be problem object in the module, especially in the static fluid topic (Aini et al., 2018; Zainuddin et al., 2018). Environmental knowledge of wetland is an effort to understand and empower the environment or areas that are partially or wholly inundated by shallow water(Iriani et al., 2019). The application of static fluid topic is effortless to find in this area. This can be one of the advantages of developing local wisdom-based teaching materials in wetland environments. Implementation of local wisdom will also form a personality based on the nation's noble value (Hartini, Isnanda, et al., 2018).

The module will also make students understand the material better because students can see its application in everyday life. The reality shows that high schools in Banjarmasin only use standard textbook so that it is less applicable. This module is suspected to be the reason for the lacknees of 
motivation and interest of students in learning physics, resulting in low student achievement in learning physics. Widodo (2017) said that if the students' activity is not started from daily life, it can make students cannot apply what is learned to solve the problem.

Therefore, the existence of contextual module based on local wisdom in the wetland environment needed by students and teachers. The local wisdom-based learning approach was chosen as an effort to improve student concepts so that students' interest in learning will increase. Module-based on local wisdom in the wetland environment will improve curiosity and change their mindset towards the environment. If students can relate academic material to their experiences, these students will find meaning in learning (Johnson, 2007). Research done by Damayanti et al. (2013) supports the statement that the love of local culture and the improvement of learning result could be obtained through local wisdom-based learning. Anggraeni and Yonanda (2018) in their study, also shows the progress in learning outcomes using local wisdom base module. So, by making a local-wisdom base module to train waja sampai kaputing character can solve this problem. Developing a good module requires some aspects of assessment. One of them is the effectiveness of the module. Therefore, the purpose of this study is to describe the effectiveness of local wisdom based static fluid modules in the wetland environment.

\section{Method}

This study is a research and development study with modified 4D model. The development contains three stages, which are defined, design and develop. In this study, the module developed is based on local wisdom in a wetland environment. The module has been tested for sixty grade XI students from two public high schools in Banjarmasin city. In the define stage, basic competencies and the characteristic of students and the topic is analized-the results of the definition than are used to get the form of the developed module. In the design stage, the module is designed based on local wisdom in the wetland environment. The steps of the design stage are: choosing the media, choosing the format of the module, and the initial design of the module. In the developing stage, the module is developed to be a good module and eligible to be implemented in class. The module then is validated based on BSNP standard. The aspects are content aspect, presentation aspect, language aspect and graphic aspect. The module that passes the validation is tested to sixty students in two schools.

The effectiveness can be obtained using $n$-gain of the average result of pre-test and post-test (Hartini et al., 2017). The effectiveness of the module is measured using a learning outcome test. The data of the study obtained from the result of pre-test and post-test then is calculated using n-gain (Hake, 1998).

\section{Results and Discussion}

The developed module is a module that is suitable for Kurikulum 2013 (2013 Curricula) for a static fluid topic. The static fluid is a topic contains procedural knowledge so the teacher can use experiment approach to find concept, principle, or law that exists in the topic. The module design developed can be seen in Figure 1.

In Figure 1, the module is designed to introduce the students about local wisdom in the wetlands environment by using the local wisdom as a problem object at the beginning of the module. Besides, local wisdom is also included in the additional information in the module. The learning model used is a guided inquiry model, so the students are facilitated to find concepts and laws in certain topic though experiment. The module consists of a cover, local information, the learning materials, scientific activities, problem examples, exercises, reflections and bibliography. The student's worksheet is included in the module to help students in doing scientific activity. The following are examples of local wisdom contained in the module, can be seen in Figure 2.

In Figure 2, local wisdom associated with static fluid material is the lanting house. This is closely related to the physics material of Archimedes' Law. Learning outcome test is developed to test the effectiveness of the module consist of questions, both in the form of calculations and applications in 
daily life. The effectiveness of the module can be seen through n-gain scores from the results of pretest and post-test. The $\mathrm{n}$-gain results can be seen in Table 1 .

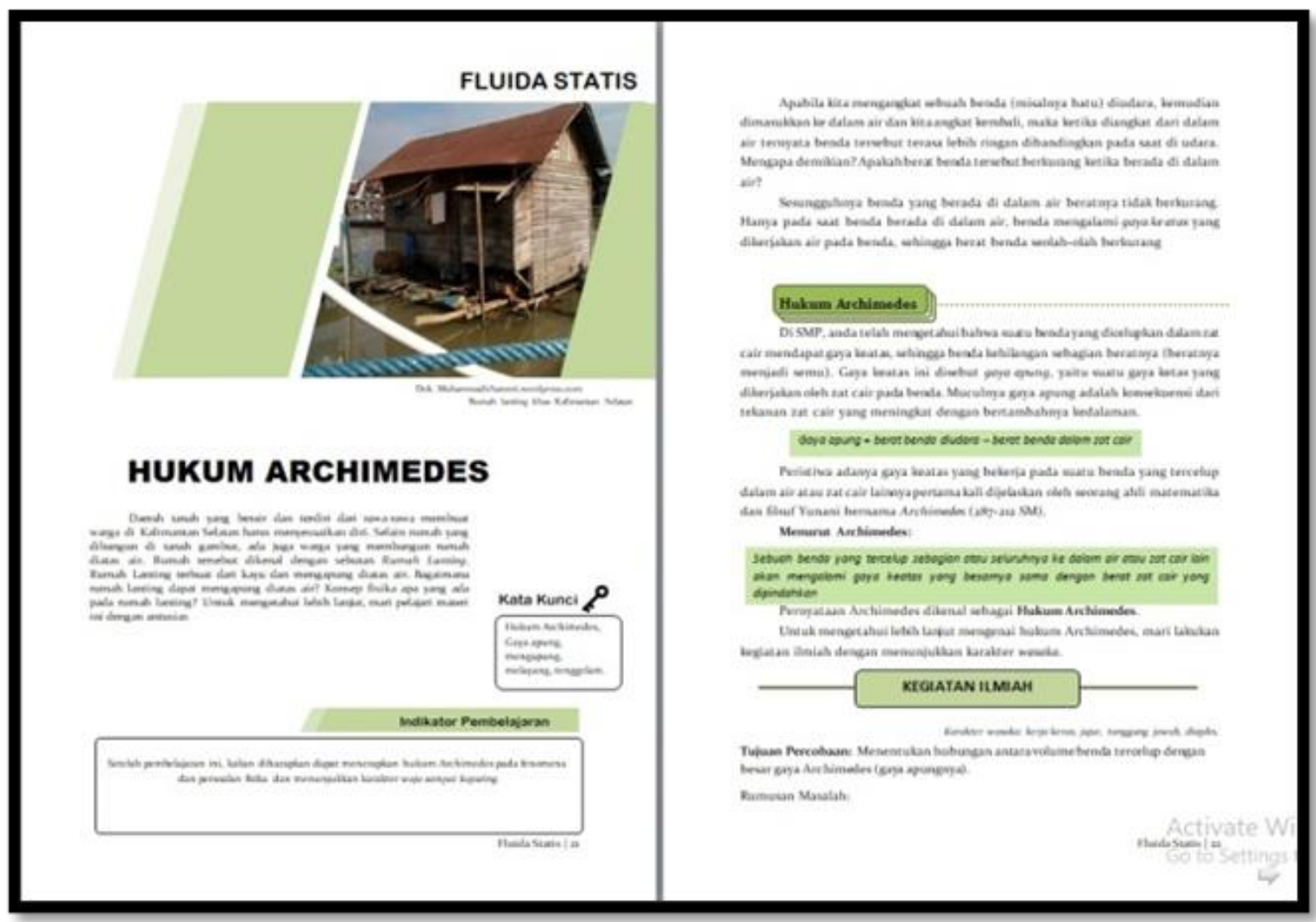

Figure 1. The design of the module

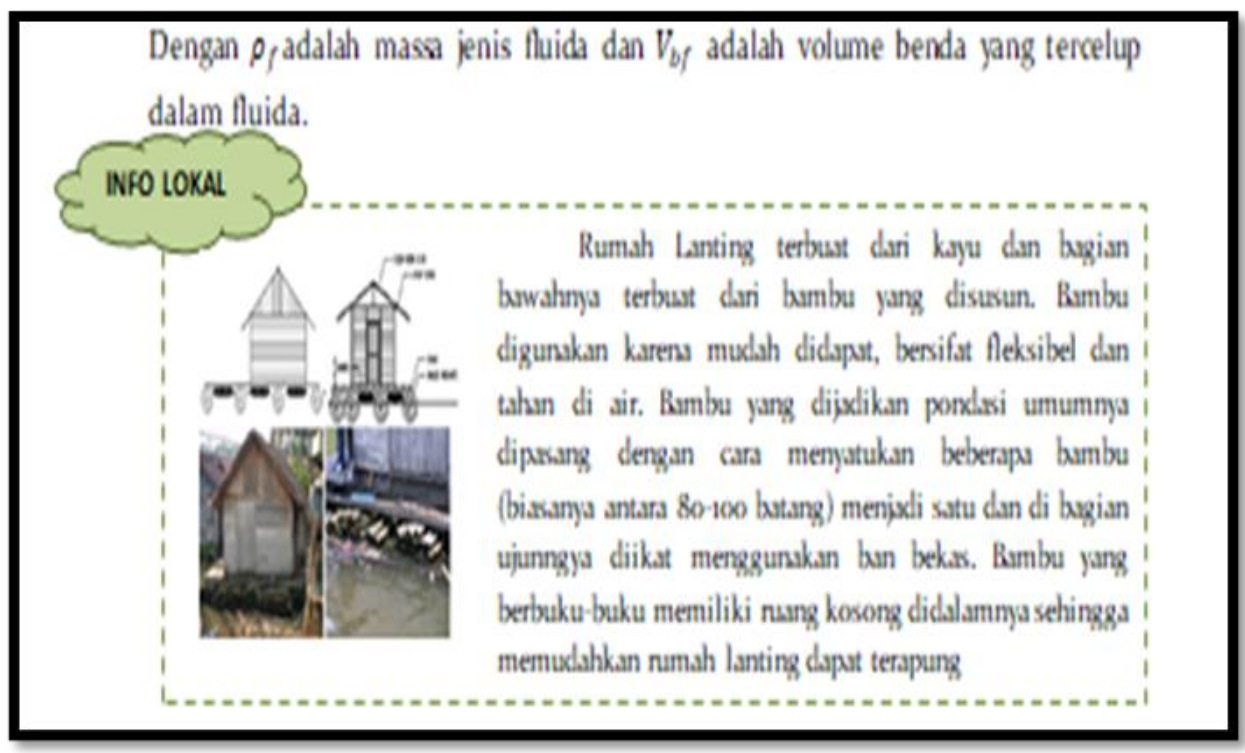

Figure 2. Local wisdom in the module

Table 1. $\mathrm{N}$-gain result

\begin{tabular}{cccc}
\hline Pretest Average & Posttest Average & $N$-gain & Category \\
\hline 4.64 & 48.03 & 0.46 & Medium \\
\hline
\end{tabular}

Table 1 shows that the effectiveness results displayed in both schools had $n$-gain in the medium category. This situation is due to several factors that affect student evaluation results. In the questions that need calculations, students still experience some difficulties. There are still many stu- 
dents who have not been able to write the variables that are known and the variables that asked in the complete question along with the symbols. This will affect the completion of students in working on the problems. According to Pólya (2014) that before solving a problem, students must understand what variables are available in the question and relate them to the variable sought. A study by Jiwanto et al. (2012) also supports the statement that the percentage of students who cannot write the variables, mostly cannot solve the problem well. Besides, the students' understandings of the question need to be improved. As in question number 4, some students do not seek total force on all four wheels, thereby reducing test results. For the questions of application in daily life, students have been able to determine the concepts and laws of static fluid that apply to these phenomena. Overall, although $n$-gain is only in the moderate category, the module is said to be effective in improving student learning outcomes. This module was developed by adjusting learning objectives so that it can support improved learning outcomes. This supported by a study from Astuti et al. (2018) stated that if the module is well-written and according to the specific aim of the learning, it will make the module effective to be used in school.

Another factor that causes this teaching material to be useful is because learning with the module is associated with local wisdom in the wetland environment. This evidenced by the large number of students who can answer the application of static fluid material in everyday life on learning achievement tests. This supported by the study by (I. N. Ihsan et al., 2017; Misbah et al., 2020), which shows that module developed by presenting problems that are close to students can improve student learning outcomes. Arends (2012) also revealed that giving issues taken in daily life support the achievement of learning objectives. Students can also easily see the application of static fluid in the module using impressive figures, so students are more motivated to learn. This was conveyed by Hartini, Firdausi, et al. (2018) in their study which showed that module effectiveness increased because students were more motivated by the module that presented the application of learning material in the form of pictures. The application of physics learning based on local wisdom effectively used in the learning process (Selvia et al., 2017; Wati et al., 2020).

This module conceptualizes the wetland environment as one of the applications of static fluid material in everyday life. This can improve students' understanding of concepts so that they can facilitate students in answering learning outcomes tests (Selvia et al., 2017; Zainuddin et al., 2018). (S. P. S. Jaya, 2012), in his study, stated that the learning outcomes increase if the teacher uses a module that conceptualizes the concept learned. Research by Asrizal et al. (2018) also shows the significant change in student outcomes before and after using the module that applies in everyday life. The arrangement of instructional materials designed so that students can construct their knowledge through experiment, so students understand the material better. This is supported by research by Matanluk et al. (2013) which states that teaching materials developed based on the principle of constructivism will make students able to solve the physics problems given by their teachers. This increase in learning outcomes is in line with Piaget's learning theory which states that students' cognitive development depends on how active students are in manipulating and actively interacting with their immediate surroundings (I. M. Jaya et al., 2014).

\section{Conclusion}

Based on the results of product development along with the results of the trial, it can be concluded that local wisdom based static fluid module in the wetland environment effectively used in learning. This supported by the effective results which categorized as medium. Teaching materials can motivate students to be more active in learning and help make it easier for students to apply static fluid material through local wisdom in the wetland environment.

\section{Acknowledgement}

Thank you to Lambung Mangkurat University (ULM) and LPPM ULM who have funded this research through the 2019 PNBP University. 


\section{References}

Aini, N., Zainuddin, Z., \& Mahardika, A. I. (2018). Pengembangan materi ajar IPA menggunakan model pembelajaran kooperatif berorientasi lingkungan lahan basah. Berkala IImiah Pendidikan Fisika, 6(2), 264. https://doi.org/10.20527/bipf.v6i2.4919

Anggraeni, K., \& Yonanda, D. A. (2018). Efektivitas bahan ajar berbasis kearifan lokal dalam model pembelajaran teknik jigsaw terhadap keterampilan menulis deskripsi. Jurnal Visipena, 9(2), 385-395. https://doi.org/10.46244/visipena.v9i2.467

Anissa, R., Mastuang, M., \& Misbah, M. (2020). Efektivitas perangkat pembelajaran fisika bermuatan lingkungan lahan basah untuk melatihkan karakter waja sampai kaputing. JPFT (Jurnal $\begin{array}{llll}\text { Pendidikan Fisika Tadulako Online, 33-39. } & \text { 8(2), }\end{array}$ http://jurnal.untad.ac.id/jurnal/index.php/EPFT/article/view/16440

Arends, R. I. (2012). Learning to teach (9th Editio). The McGraw-Hill Companies, Inc.

Asrizal, A., Amran, A., Ananda, A., \& Festiyed, F. (2018). Effectiveness of adaptive contextual learning model of integrated science by integrating digital age literacy on grade VIII students. IOP Conference Series: Materials Science and Engineering, 335(1), 012067. https://doi.org/10.1088/1757-899X/335/1/012067

Astuti, M. W., Hartini, S., \& Mastuang, M. (2018). Pengembangan modul IPA dengan menggunakan model pembelajaran inkuiri terbimbing pada materi suhu dan kalor untuk melatihkan keterampilan proses sains. Berkala Ilmiah Pendidikan Fisika, 6(2), 205. https://doi.org/10.20527/bipf.v6i2.4934

Damayanti, C., Dewi, N. R., \& Akhlis, I. (2013). Pengembangan CD pembelajaran berbasis kearifan lokal tema getaran dan gelombang untuk siswa SMP kelas VIII. Unnes Science Education Journal, 2(2), 274-281. https://doi.org/10.15294/USEJ.V2I2.2036

Hake, R. R. (1998). Interactive-engagement versus traditional methods: A six-thousand-student survey of mechanics test data for introductory physics courses. American Journal of Physics, 66(1), 64-74. https://doi.org/10.1119/1.18809

Hartini, S., Firdausi, S., Misbah, M., \& Sulaeman, N. F. (2018). The development of physics teaching materials based on local wisdom to train Saraba Kawa character. Jurnal Pendidikan IPA Indonesia, 7(2), 130-137. https://doi.org/10.15294/jpii.v7i2.14249

Hartini, S., Isnanda, M. F., Wati, M., Misbah, M., An'nur, S., \& Mahtari, S. (2018). Developing a physics module based on the local wisdom of Hulu Sungai Tengah regency to train the murakata character. Journal of Physics: Conference Series, 1088, 012045. https://doi.org/10.1088/17426596/1088/1/012045

Hartini, S., Misbah, M., Helda, \& Dewantara, D. (2017). The effectiveness of physics learning material based on South Kalimantan local wisdom. AIP Conference Proceedings (Vol, 070006. https://doi.org/10.1063/1.4995182

Hasani, N. L., Hartini, S., \& Annur, S. (2019). Meningkatkan keterampilan proses sains dan karakter kayuh baimbai melalui modul fisika bermuatan kearifan lokal. Jurnal Ilmiah Pendidikan Fisika, 3(2), 65. https://doi.org/10.20527/jipf.v3i2.1034

Ihsan, I. N., Jamal, M. A., \& M., A. S. (2017). Pengembangan perangkat pembelajaran berorientasi lingkungan sekitar bantaran Sungai Barito untuk melatihkan keterampilan proses sains. Berkala Ilmiah Pendidikan Fisika, 5(1), 29. https://doi.org/10.20527/bipf.v5i1.2224

Ihsan, I., Yulkifli, \& Festiyed. (2019). Analysis of electronic module development using model inquiry based learning with approach contextual teaching and learning in physics material of senior high school class X. Journal of Physics: Conference Series, 1317(1), 012160. https://doi.org/10.1088/1742-6596/1317/1/012160

Iriani, R., Herlina, A., Irhasyuarna, Y., \& Sanjaya, R. E. (2019). Modul pembelajaran problem-based learning berbasis lahan basah untuk mempersiapkan calon pendidik berwawasan lingkungan 
lahan basah. Jurnal Inovasi Pendidikan IPA, 5(1), 54-68. https://doi.org/10.21831/jipi.v5i1.23337

Jaya, I. M., Sadia, W., \& Arnyana, I. B. P. (2014). Pengembangan Perangkat pembelajaran biologi bermuatan pendidikan karakter dengan setting guided inquiry untuk meningkatkan karakter dan hasil belajar siswa SMP. Jurnal Pendidikan Dan Pembelajaran IPA Indonesia, 4(1), 1-12. https://ejournal-pasca.undiksha.ac.id/index.php/jurnal_ipa/article/view/1065

Jaya, S. P. S. (2012). Pengembangan modul fisika kontekstual untuk meningkatkan hasil belajar fisika peserta didik kelas X semester 2 di SMK Negeri 3 Singaraja. Jurnal Teknologi Pembelajaran Indonesia, 1(2), 1-23. https://doi.org/10.23887/jtpi.v1i2.301

Jiwanto, I. N., Purwanto, J., \& Murtono, M. (2012). Analisis kesulitan siswa dalam memecahkan masalah fisika menurut Polya. Prosiding Seminar Nasional Fisika Dan Pendidikan Fisika, 3, 414422.

Johnson, E. B. (2007). Contextual teaching and learning: Menjadikan kegiatan belajar mengajar mengasyikkan dan bermakna. Mizan Learning Center.

Matanluk, O., Mohammad, B., Kiflee, D. N. A., \& Imbug, M. (2013). The effectiveness of using teaching module based on radical constructivism toward students learning process. Procedia Social and Behavioral Sciences, 90(InCULT 2012), 607-615. https://doi.org/10.1016/j.sbspro.2013.07.132

Misbah, M., Hirani, M., Annur, S., Sulaeman, N. F., \& Ibrahim, M. A. (2020). The development and validation of a local wisdom-integrated physics module to grow the students' character of Sanggup Bagawi Gasan Masyarakat. JIPF (Jurnal IImu Pendidikan Fisika), 5(1), 1. https://doi.org/10.26737/jipf.v5i1.1280

Misbah, M., \& Wati, M. (2020). The practicality of physics teaching materials based on local wisdom in the wetland environment. Proceedings of the 1st South Borneo International Conference on Sport Science and Education (SBICSSE 2019). https://doi.org/10.2991/assehr.k.200219.053

Oktaviana, D., Hartini, S., \& Misbah, M. (2017). Pengembangan modul fisika berintegrasi kearifan lokal membuat minyak lala untuk melatih karakter sanggam. Berkala Ilmiah Pendidikan Fisika, 5(3), 272. https://doi.org/10.20527/bipf.v5i3.3894

Pólya, G. (2014). How to solve it: A new aspect of mathematical method. Princeton University Press.

Selvia, M., Arifuddin, M., \& Mahardika, A. I. (2017). Pengembangan bahan ajar fisika SMA topik fluida berorientasi masalah lahan basah melalui pendekatan contextual teaching and learning (CTL). Berkala Ilmiah Pendidikan Fisika, 5(2), 213. https://doi.org/10.20527/bipf.v5i2.2896

Utari, U., Degeng, I. N. S., \& Akbar, S. (2016). Pembelajaran tematik berbasis kearifan lokal di sekolah dasar dalam menghadapi Masyarakat Ekonomi Asean (MEA). Jurnal Teori Dan Praksis Pembelajaran IPS, 1(1), 39-44. https://doi.org/10.17977/um022v1i12016p039

Wati, M., Hartini, S., Misbah, M., \& Resy, R. (2017). Pengembangan module fisika berintegrasi kearifan lokal hulu sungai selatan. Jurnal Inovasi Dan Pembelajaran Fisika, 4(2), 157-162. https://doi.org/10.36706/jipf.v4i2.5411

Wati, M., Putri, M. R., Misbah, M., Hartini, S., \& Mahtari, S. (2020). The development of physics modules based on madihin culture to train kayuh baimbai character. Journal of Physics: Conference Series, 1422, 012008. https://doi.org/10.1088/1742-6596/1422/1/012008

Widodo, W. (2017). Efektifitas penggunaan bahan ajar berbasis kontekstual berbantuan video pembelajaran untuk SMK teknik mesin pada materi elektrokimia. Seminar Nasional Pendidikan IPA, 2, 365-372. http://pasca.um.ac.id/conferences/index.php/ipa2017/article/view/1116

Zahro, U. L., Serevina, V., \& Astra, M. (2017). Pengembangan lembar kerja siswa (LKS) fisika dengan menggunakan strategi relating, experiencing, applying, cooperating, transferring (react) berbasis karakter pada pokok bahasan hukum Newton. WaPFi (Wahana Pendidikan Fisika), 2(1), 63-68. https://doi.org/10.17509/wapfi.v2i1.4906 
Momentum: Physics Education Journal, 4 (2), 2020, 108

Mustika Wati, Misbah Misbah, Surya Haryandi, Dewi Dewantara

Zainuddin, Z., Afnizar, H. A., Mastuang, M., \& Misbah, M. (2018). Developing a teaching material oriented to science and technology and local wisdom in wetland environment. Proceedings of the 1st International Conference on Creativity, Innovation and Technology in Education (IC-CITE 2018). https://doi.org/10.2991/iccite-18.2018.68 